\title{
Representation of the Social Dynamics of Ex-Localization Communities in Doll's Batik, Surabaya
}

\author{
Aniendya Christianna ${ }^{1}$, Mariana Wibowo², and Poppy Firtatwentyna Nilasari² \\ ${ }^{1}$ Visual Communication Design, Faculty of Art and Design, Surabaya, Indonesia \\ ${ }^{2}$ Interior Design, Faculty of Art and Design, Surabaya, Indonesia
}

\section{Abstract}

Since the 1960s the largest prostitution area in Southeast Asia has been located in the Dolly-Jarak borough, Putat Jaya urban village, Sawahan sub-distict, Surabaya City, Indonesia. The Surabaya City Government officially declared the borough closed on June 18, 2014. Ending the prostitution business not only requires this closure but must be accompanied by an impactful and sustainable alternative professions for those involved. Training provided by the government includes making snacks, herbal drinks, crafts, fashion products, household products, sewing and batik. Since 2014, Batik

Corresponding Author: Aniendya Christianna aniendya@petra.ac.id

Received: Month 2020 Accepted: Month 2020 Published: Month 2020

Publishing services provided by Knowledge E

(c) Aniendya Christianna et al. This article is distributed under the terms of the Creative Commons Attribution License, which permits unrestricted use and redistribution provided that the original author and source are credited.

Selection and Peer-review under the responsibility of the ICADECS Conference Committee.
SMEs (Small Medium Enterprises) have increased significantly owing to demand from housewives since UNESCO declared batik as Masterpieces of the Oral and Intangible Heritage of Humanity on October 2, 2009. Every region in Indonesia competes to produce unique batik motifs representing the identities of their respective communities. This includes the Dolly-Jarak village, Sawahan sub-distict, which has a unique motif. Since 2014 the butterfly motif with its various variants has dominated batik in the region of Dolly's ex-localization. This research was conducted in February-July 2019 with the aim of finding out the meaning of Dolly's unique batik motifs which became the visual dialectic of Dolly's ex-localization residents with their social problems. Visual methodology (Gillian Rose) becomes the method of analysis, especially in the area "site of image it self" and "the site of the production". The researcher acts as an interpreter of the batik motifs based on the theory of design of visual communication. The visual sorting process produces meaning, which is analysed using Barthes' semiotics and associated with the socio-cultural context in which batik is produced. This research produced (1) the symbolic meaning of the butterfly motif, (2) the symbolic meaning of the colors that dominated batik in the Dolly's ex-localization, and (3) the butterfly as a symbol of hope and a better future for Dolly's residents. Through this research, we can find out about the future hopes of Dolly"s village after the closure of the localization.

Keywords: Dolly's Ex-localization, Batik, Butterflies, Visual Methodology, Barthes Semiotics

\section{Introduction}

Since the 1960s the largest prostitution area in Southeast Asia was in the Dolly's exlocalization, Putat Jaya urban village, Sawahan sub-distict, Surabaya City [1]. 
Hundreds of guesthouses with hundreds of pimps and thousands of prostitutes operated everyday. Until 2014 it was officially closed by the Surabaya city government based on Regional Regulation number 6 of 2013 which regulates the prohibition of immoral acts and the using of building as a place of immoral practice. Human trafficking, consumption and distribution of illegal drugs, alcohol, rape, sexual harassment of women and children, domestic violence, spread of sexually contagious diseases and HIV/AIDS, fraud, embezzlement, fighting, stealing, and other criminal activities are the negative effects of the Dolly-Jarak"s localization existence among society. Based on the consideration of the negative impacts, the Surabaya city government cooperated with the East Java provincial government to close the Dolly-Jarak"s localization area. The local government did not only close Dolly-Jarak"s localization, but also made various sustainability efforts as a form of anticipating the impact of the closure. Mainly in terms of economy and livelihood of the local community. It was undeniable that pimps and prostitutes came from outside the city of Surabaya, on the other hand local people depended their daily income from the operation of prostitution, such as opening a parking lot, salon services, laundry, rent toilet. With the closure of the Dolly-Jarak"s localization, small businesses that had been operated for a long time were affected, some had to close, some didn't get as much profit as before. To deal with the impact of post-closure Dolly-Jarak"s localization, the city government is working with various parties to make efforts for coaching and supervision through participatory community empowerment programs. The Surabaya city government appointed several agencies in carrying out programs to strengthen the capacity of affected communities arround area of closure of the Dolly-Jarak"s localization.

The city government of Surabaya realizes that the closure of localization is not only about ending theprostitution business, but also should be accompanied by an impactful and sustainable solution. As a follow-up to the closure, the Surabaya City Government replaced the localization of Dolly"s prostitution by providing venture capital assistance, opening CSR cooperation from companies, working with universities, communities and other parties concerned with affected residents. The trainings included making snacks, crafts, fashion products, household products, herbal drinks, sewing and making batik. Since 2014, until now at least there are15 UKM have been formed. They produce Batik actively and exhibit it in various national and international events. Among others, namely Batik Alpujabar (made by Mr. Sutrisno), Batik Jarak Arum (made by Ms. Fitri), Batik Warna Ayu (made by Ms.Siti) dan Batik Kriya Punden (made by Ms. Mastuka). Dolly"s Batik is known for its distinctive variants of motifs, such as butterflies, Jatropha leaves, historical monuments, Clover leaves and Surabaya mythological animals:,Suro’ sharks and„Boyo’ 
crocodiles. The motifs are in the form of stylation and simplification of the shape of the original object.

The batik craftsmen are residents of Sawahan sub- distict, Surabaya city, where the prostitution business used to develop. All craftsmen are of Javanese descendants who hold to the philosophical values of Javanese culture. Javanese culture is one of the members of Asian culture that uses more symbolic language to express the thoughts of their lives. Mythology cannot be separated from Javanese. Through mythology, Javanese people understand the definition of the Javanese world. Javanese people live united with mythology which is full of symbolization. Javanese culture which is full of these symbols has taught them a lot about the wisdom of their life. Javanese philosophy that contains many symbolic is contained in various art forms. Art and society have complex relationships. A work of art cannot be separated from the socio-cultural background where the artist lives. Aesthetic-artistic artistic experience, community experience, and transcendent experience become important backgrounds about the creative process of creating a work of art [2]. One of the artworks is Batik. Reading Dolly"s Batik motifs and identifying their symbolic meaning aims to find out the social dynamics of Dolly"s residents and their future life expectancy.

\section{Literature Review}

\subsection{Javanesse Culture}

"Java" which is another name of "Djawa Dwipa" is an island located on the southern edge of the Indonesian archipelago. The Javanese support and live the Javanese Culture. The Javanese live in the area of origin of Javanese culture: Central Java and East Java. The

Javanese have opinion that culture is not homogeneous. They are aware of regional diversity, throughout the regions of Central Java and East Java. Regional diversity of Javanese culture is more or less compatible with the Javanese dialect area and also appears in aspects of their lives, such as: food, traditional ceremonies, household, folk art and tembang [3].

For Javanese 'culture' is not a vague anthropological concept, but the nature of humans as social beings. The life of Javanese people cannot be separated from the environment where they live. They will always depend on and interact with their environment through a series of experiences and observations, both directly and indirectly and consciously or unconsciously. From this life experience, they understand the 
environment in where they live, in which it provides clues as what is good and bad for their lives.

Based on the description above, it is clear that the definition of Javanese culture is the embodiment of Javanese human mind that tells the will, ideals, hope, and enthusiasm in achieving prosperity, safety and happiness in physical and spiritual life.

\subsection{Dolly's Batik}

Batik SMEs (Small Medium Enterprises) in the Dolly"s ex-localization area has grown since the prostitution business was closed in 2014. There are at least 15 Batik SMEs (Small Medium Enterprises) that are currently developing and actively producing. Batik SMEs (Small Medium Enterprises) in Dolly is mostly initiated and managed by women (housewives). The distinctive features of Dolly" Batik accentuate feminine motifs by stylizing the shape of butterflies, Jatropha leaves, various flowers and other distinctive forms of Surabaya (such as the Hero monument, Suro-Boyo statue, Bambu Buncing statue and Clover leaves). The Surabaya City Government facilitates showrooms, galleries and showrooms to market Batik by Batik SMEs (Small Medium Enterprises) from Dolly, in the following locations: Sentra UKM Merr, Sentra UKM Siola, Sentra UKM Juanda and Sentra UKM North Quay. Even some batik has been appreciated by designer Oscar Lawalata and exhibited to abroad.

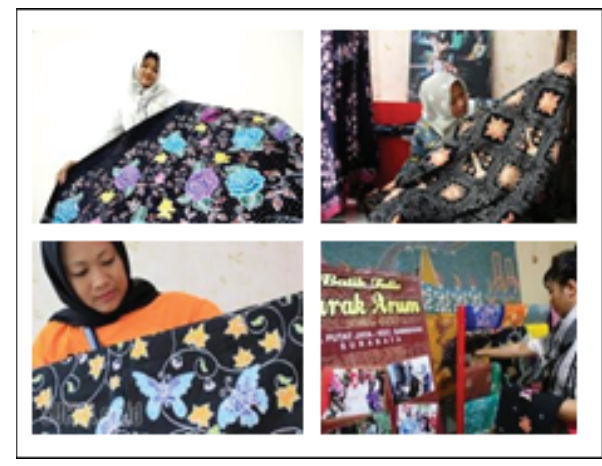

Figure 1: Dolly"s Batik: Batik Jarak Arum

\subsection{Overview of Image Elements}

\subsubsection{Line}

The presence of a line is not just a line but sometimes as a symbol of emotion expressed through a line, or more accurately called a scratch. Scratch will give a different 
psychological impression on each line presented. The line is the simplest medium, as the most economical achievement compared to other media. Lines as a medium of art have a very important role, as long as a reader is able to capture information conveyed through the medium of the line presented. Every line that is scratched has its own strengths that need understanding. The line should be able to understand through the inner eye and needs sensitivity to capture every vibration that is found in every scratch [4].

\subsubsection{Color}

Color is an impression caused by light in the eyes [5]. Color is one of the elements in arts, either pure and applied arts that play a role in all aspects of human life. Thus the close relationship of color in human life, so it can be understood that color has a very important role, such as: color as color, color as a representation of nature, color as a sign, and color as a symbol of expression. Color standardized by Albert H. Munsell (1912) complements the system of color numbers and terminology, based on investigations on color standardization that can be used for physical and psychological aspects. The Munsell system bases on the dimensions of color quality, namely: hue, value and intensity or chroma. The presence of color is a symbol or symbolizes something that is a common tradition or pattern. Also the presence of colors to give a certain sign that is already a common habit or general pattern, eg red, green, and yellow signs of street lights.

\subsubsection{Shape and Space}

Shape is a small area that occurs because it is limited by a contour (line) and / or is limited by the presence of different colors or by dark light in shading or because of the texture. Shape is used as a symbol of feeling in describing the object matter subject matter. This is due to the shape (bangun) changes in appearance (transformasi) in the processing of objects [6]. Stilization (1), by contouring on each object or area of surface. Distortion (2), is the depiction of forms that emphasize the attainment of character, by emphasizing certain forms on things or objects drawn. Disformation (3), is a depiction of the form that emphasizes the interpretation of characters by changing the shape of the object by describing the object and taking certain elements that represent the results of the interpretation that are very essential. 


\subsection{Representation}

According to Hall in his book : Representation: Cultural Representation and Signifying Practices,

"Representation connects meaning and language to culture... Representation is an essential part of the process by which meaning is produced and exchanged between members of culture" [7].

Through representation, a meaning is produced and exchanged between members of the community. So it can be said that, a brief representation is one way to produce meaning.

Representation works through a representation system. This representation system consists of two important components, namely concepts in mind and language. These two components are interrelated. The concept of something that is possessed in the mind, makes individuals know the meaning of that thing. However, meaning cannot be communicated without language. Therefore, the most important thing in this representation system is that groups that can produce and exchange meaning well are certain groups that have a common background of knowledge so that they can create an (almost) the same understanding.

\section{According to Stuart Hall :}

Member of the same culture must share concepts, images and ideas which enable them to think and feel about the world in roughly similar ways. They must share, broadly speaking, the same,culture codes“. In this sense, thinking and feeling are themselves „system of representations“.

As a system of representation, thinking and feeling also function as giving meaning to something. Therefore, to be able to do something requires the same background of understanding of concepts, images and ideas (cultural codes). The process of giving meaning to something can be very different in different cultures or groups of people because in each culture or group of people there are separate ways of interpreting things. Groups of people who have different backgrounds in understanding certain cultural codes will not be able to understand the meanings produced by other community groups. The meaning is nothing but a construction. Humans construct meaning very firmly so that a meaning looks likes natural to be accepted and cannot be changed. Meaning is constructed through a system of representation and diffication through code. This code makes people who are in the same cultural group understand and use 
the same term to describe something, after going through the process of convention socially. Thus, the code builds a correlation between the conceptual system that exists in the mind with the language system used. So it can be concluded that representation is a process for producingmeaning from concepts that are in mind through language. The process of producing meaning depends on the background knowledge and understanding of a social group on a sign. A group must have the same experience to be able to interpret something almost in the same way.

\subsection{Visual Methodology}

Signs are the basis of all human communication. With the mediation of signs, humans can communicate with their neighbor. Many things can be communicated in this world. A sign indicates something other than itself and the process of giving meaning (meaning) is the relationship between an object / idea with a sign [8].

Visual text is the final appearance that can be observed, which in this case is separated from the discussion of verbal texts. Visual text consists of everything that can be observed physically such as visual works, colors, decoration elements, photographs and or character images, including Batik. In this study, researchers used a discourse analysis approach based on a critical paradigm. Discourse analysis is an analysis used to see the use of symbols in the form of compositions of other shapes and colors as social practices [9].

\subsection{Barthes Semiotic Analysis}

Roland Barthes is a follower of Saussure's thought. This can be proven from Barthes's semiotic theory almost literally derived from language theory according to de Saussure. According to Barthes, semiology is learning about how humans interpret something around them. So the object is a sign that carries the implied message. In Saussure's view, he emphasized marking only at the level of denotation and connotation. However, in Barthes' thinking, the marking was supplemented by Saussure's semiology with a connotative and mythical marking system [10]. The first level significance system and the second level significance system connotation. In the sense of Sobur [11], the meaning of denotation is a word whose meaning can be found in a dictionary. Denotation expresses the meaning of what is seen by the eye, the meaning of denotation is the true meaning. So, the meaning of denotation is the first level of meaning, what is seen by the eye is what is believed to be true. Whereas connotation has subjective and varied meanings, it 
can be said that the connotation of how we describe it. The connotation or significance of the second level of meaning is to express the meaning contained in the signs. In this significance it is believed that there is a meaning behind it. In the Barthes"s framework, there is another aspect of labeling, 'myth'. The myth that Barthes explains is not a myth in the sense that develops in society, such as: having superstitious or implausible meaning. But, Barthes"s myth is a language, myth is a message. Quoted from the book Semiotics in Communication Research,

Barthes also said that myth is a semiological system, which is a system of signs which is interpreted by humans. Myth is a development of connotation. So, if the connotation has long been formed in the community then it becomes a myth.

\section{Methodology}

The method used to study this research is a critical analysis method of visual discourse, with a visual methodology in interpreting visual material. A work of art / design that symbolizes the image means reflecting the status of the maker. So all the elements that make up a visual work are a set of signs that can be seen as meaningful cultural representations. So that visual methodology is considered important in dissecting meanings articulated by a series of signs.

This qualitative research uses the qualitative approach of the critical study method with image based research, which is researching and revealing visual images as a basis for research. In the process of interpretation, the researcher will do the dialectic process with the text as an object. Then analyzed using Barthes semiotics so that it becomes a unity. Furthermore, relative reality will be obtained. This means that the researcher assumes that reality is the result of mental construction of individual social actors, hence the reality is understood differently by each individual.

\section{Discussion}

\subsection{Social Dynamics in Butterfly Symbolism}

The philosophy and attitude of Javanese life are the products of creation, taste, and intention as a reflection of the reality of life. Javanese way of life is much influenced by the culture of animism-dynamism, Hinduism, Buddhism, and Islam. The use of symbols is something unique because it is only done by humans. Symbols are a form of indirect communication, meaning that in communication there are hidden messages so that 


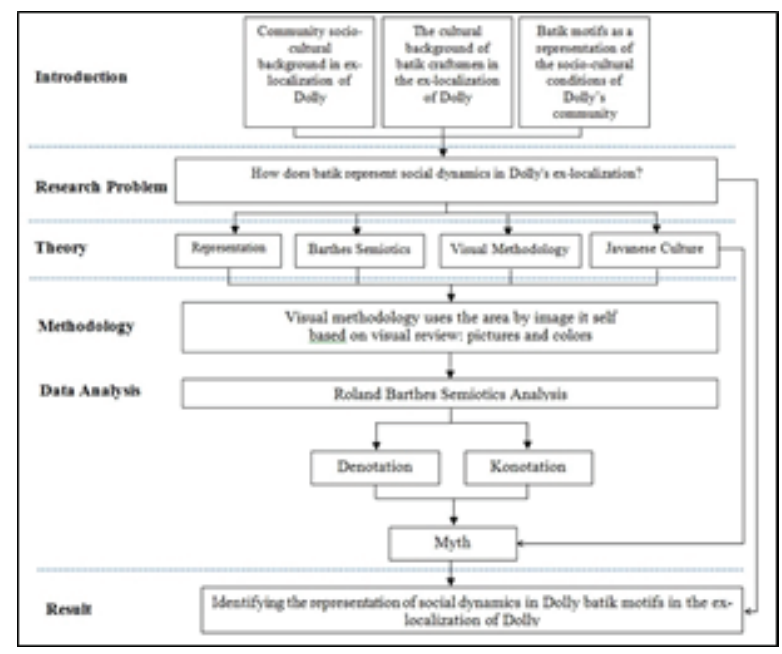

Figure 2: Framework of Thinking

the meaning of a symbol is very dependent on individual interpretation. In Javanese world, the moral teachings are not conveyed openly or frankly but through various symbols. This is in accordance with the character of the Javanese who likes to say everything indirectly as revealed in the proverbs: wong Jawa nggone semu, sinamun ing samudana, sasadone ingadu manis: Javanese tend to be artificial or veiled, full of symbols, and like to convey hidden words and images [12].

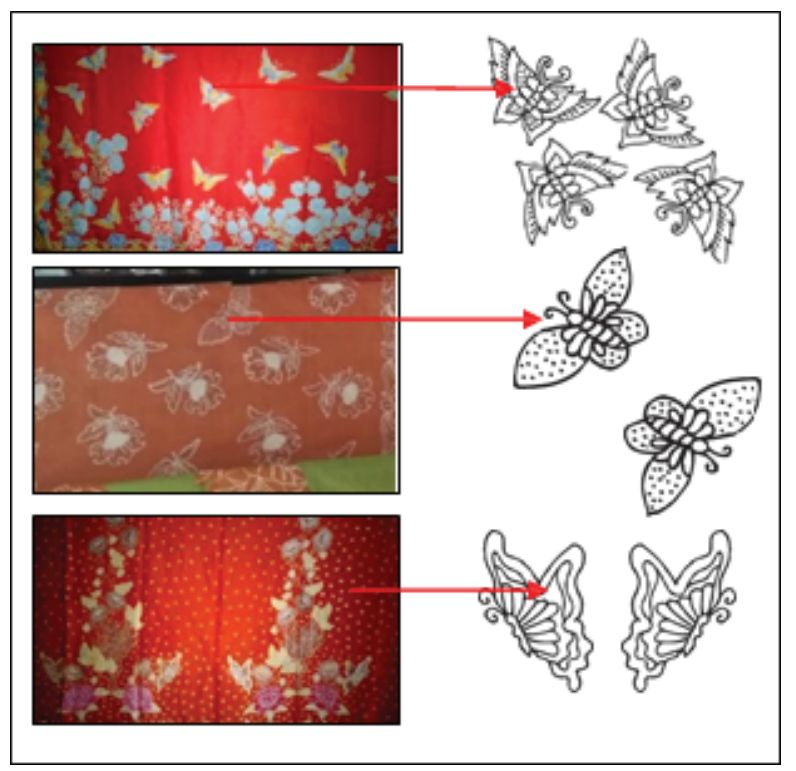

Figure 3: Visual Analysis of Butterfly“s Batik Motifs

The Batik craftsmen in the ex-localization of Jarak and Dolly are descendants of the Javanese. Where their view of life, beliefs and culture are closely related to symbols. The symbols are manifested in various aspects of life, ranging from language, actions, rituals, food, art, clothing including Batik. Most of the batik works by UKM in the Dolly"s 
ex-localization have butterfly with spreading wings motif. Butterfly motifs are drawn in a stylized way, where the piction is made in such a way as to achieve a form of beauty by presenting objects based on creativity and still being inspired from the original object. Based on interviews and focus group discussions with batik craftsmen, the inspiration for butterfly batik motifs comes from the socio-cultural background of the Sawahan subdistrict area, which was once dominated by prostitution and localization businesses. The prostitution business that developed since the $60 \mathrm{~s}$ in the region of Jarak-Dolly was driven by pimps/brokers and prostitutes. Because of the high demand in the prostitution business, more and more women are working as prostitutes, some from the Dolly"s area, some from outside the city. There has been a popular term for a prostitute:,kupu-kupu malam' 'Kupu-kupu malam' is just the equivalent of the word prostitute: PSK, tunasusila, ciblek, lonte, WTS and other terms that refer to selling sex services job. The term „KupuKupu Malam" became popular since the senior singer: Titiek Puspa coined and sang a song called „Kupu-kupu malam” on 1977. Then sang again by the band Peterpan (now Noah Band) in the 2000s. Since then the poetic term about prostitutes is embedded in people's minds. Butterfly is an analogy for women because of their beauty. Women and butterflies are both judged by their physical appearance: what they wear, how they look, and how their hair is styled. Women are like objects that are enjoyed only by their beauty, without respecting the other side of humanity.

Unlike the Javanese philosophy of looking at and valuing butterfly. The batik craftsmen who are all Javanese (and most are Muslim) cannot be separated from a life filled with symbolism and myth. Javanese believe that their life must be in harmony between microcosm and macrocosm, maintaining harmony with God, humans and the universe[13]. From these beliefs, Javanese pays attention to the natural phenomena as a sign of other events. One of the well-known and often experienced myths is related to the coming butterflies in the house. The Javanese believe that the butterfly that enters the house symbolizes there will be guests coming. If a butterfly enters who enter the house has beautiful wings color, it is said that it will bring goodness / fortune. And if the butterfly has dark spooky wings then what comes is a bad thing/disaster.

The mind of the Javanese formulates human life in two cosmos (realm) namely macrocosm and microcosm. Macrocosm in the Javanese mind is a behavior and attitude to life towards the universe that contains supernatural powers and full of things that are mysterious[14]. Whereas the microcosm in the Javanese mind is the behavior and attitude of life towards the real world. The main goal in life is to find and create harmony or balance between macrocosm and microcosm. The Javanese believe that the universe has a hierarchy that is shown through the stages of the world to perfection: 
the under-world world, the middle-upper world, and God is the center of everything. The underworld (bhurloka) is the world of the dead, the middle world (bhuvarloka) is the world that is inhabited by humans and the upper world (svarloka) is a place of gods, ancestors and heroes [15]. The upper world is symbolized by a variety of animals that can fly, have wings and are identical to the air element (in sedulur papat limo pancer: earth, water, fire and air)[16].

Butterfly, just like bird, can fly high to symbolize the world above and the air. $\mathrm{He}$ made winged creature as one of the symbols of the perfection of life because it was considered a symbol of the desire of the Javanese to reach the nobility of character and welfare, both physically and mentally. Butterfly is also a symbol of a strong will to start and live life. Since the caterpillar, the cocoon then becomes a butterfly, the process that must be undertaken is not easy and requires a struggle.

\subsection{Bright Colors In Dolly Batik}

Color can be understood in three levels. First is color for coloring. Second, color in harmony that reveals optical reality. Third, color that used as a symbol. Based on Javanese beliefs, people interpret their lives in symbols and it is inseparable from the color aspect.

Dolly"s Batik colors tend to use bright colors and contrasts typical of coastal Batik. Unlike the inland Batik from Yogyakarta and Surakarta which tend to use soga/brick red/dark ground colors. Those colors such as : red, yellow, brown and blue are often used by artisans in Dolly's ex-localization.

It is similar with sedulur papat limo pancer[17], in symbolic world of Java there is the term mancapat and mancawarna. Everything in the world is divided into four which are spread in the four winds and one in the middle as the center. Color is also divided into four: black is located in the north, while red is in the south. White is placed on the east, and west has yellow. The red color symbolizes life and birth. The red color is associated with the hope of a better life, more luxurious, more prosperous and happier. The red color in Javanese culture is identified with the element of fire. The main source of fire/heat is the sun, humans cannot live without sunlight and heat. This passion in humans always arouses feelings of heat/wants to be angry, but at the same time illustrates the fiery struggle and never give up. The flame always leads upward, upright, and challenging, nothing to the side, let alone downward. If directed to the side or down automatically the flame will keep on trying in an upright position. Furthermore, yellow is 
an air symbol associated with the upper world (svarloka). Yellow symbolizes the glory and prosperity that can increase authority.

The red and yellow colors dominate Batik that made by Batik SMEs (Small Medium Enterprises) in Dolly"s ex-localization, it brings symbolic hope to a better future. The prostitution business that has been closed by the government has had a big impact on their lives. Even though in the past they had prospered physical/material/ mental, but their source of livelihood depended on the

'underworld' which was full of lust and neglected inner satisfaction with God and others. The business of prostitution is not a good way of life that justified in their religious and cultural teachings. With the establishment of Batik SMEs (Small Medium Enterprises) that

empowers residents of Jarak and Dolly"s ex-localization, it is expected that people's live will be better after this. Like a bright red-yellow butterfly batik motif that illustrated kindness. Those motifs describe their life's expectation which is prosperous and in harmony physically and mentally.

\subsection{Butterfly: A Symbol of Hope for the Dolly ex-Localization's Res- ident}

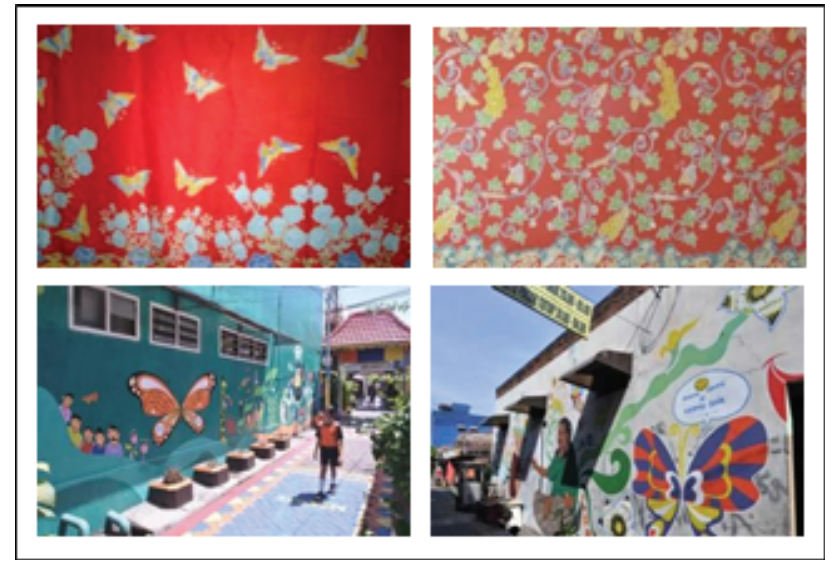

Figure 4: Butterfly as a Dolly“s icon (on batik and murals)

After being established by UNESCO in 2009 , many people make and wear batik in Indonesia. Nowadays, almost every region in Indonesia has a batik industry center that provides a variety of motifs as local superior products. In Surabaya, batik is also widely produced by the community as a form of regional product. In the process of creating batik motifs in each region has a characteristic shape and color that is based on the 
principles in the local area. Each style contains certain symbols which have certain meanings.

The butterfly is a symbol of change in Dolly resident"s identity. The closure of Dolly"s ex-localization did not only have an economic impact, but also socio-culture. Like the metamorphosis of an ugly caterpillar and cocoon, eventually it turns into a beautiful butterfly and can fly high. The process is not easy, it takes a long time, but the Dolly's resident who are also Javanese realize that harmony of life (top-down) needs to be fought for. Butterfly likes bird that can fly high, they symbolize the world above and the air. Air is a symbol of fairness and humanity. The inspiration of winged creature is one of the symbols of the perfection for Javanese's life because it is considered as a symbol of the Javanese who are longing to reach the nobleness of both character, physical and spiritual. Thus, the prayers and hopes of the Dolly"s residents are contained in every scratch of his batik motif.

\section{Conclussion}

The Javanese philosophy of seeing and valuing butterflies is a symbol of Dolly's identity that has changed to a better life. The Javanese (including batik artisans) cannot escape from a life filled with symbolism harmony between microcosm and macrocosm, thus they maintain the harmony with God, other people and the universe. From these beliefs, Javanese pays attention to natural events as a sign of other events. Butterflies inspire Dolly's distinctive batik motifs not as a form of remembrance of the "Kupu-Kupu Malam" that once existed. As a representation of social dynamics that occur in Dolly's exlocalization society, such as ugly caterpillars that turn into beautiful butterflies. Butterfly also represents the upper world (svarloka) in Javanese philosophy which symbolizes the desire of the Javanese to reach the nobility of character and welfare both physically and mentally.

\section{Acknowledgment}

1. Program studi Desain Komunikasi Visual dan Desain Interior Fakultas Desain Universitas Kristen Petra

2. Lembaga Penelitian dan Pengabdian Masyarakat (LPPM) Universitas Kristen petra

3. Kementerian Riset, Teknologi Dan Pendidikan Tinggi (Ristekdikti) Republik Indonesia 
4. Dinas Perindustrian dan Perdagangan Pemerintah Kota Surabaya 5. Rumah Batik Putat Jaya Kota Surabaya JI. Putat Jaya Gang VIII Surabaya

6. Batik SMEs (Small Medium Enterprises) Tulis Jarak Arum Jl. Putat Jaya Punden II/33 Surabaya

7. KUB Batik Tulis Alpujabar, JI. Putat Jaya Barat 9B/31 Surabaya, .

8. UKM Eco Print Sohiba JI. Sidomulyo IIE/16 Surabaya

9. UKM Kriya Punden Batik Jl. Putat jaya Punden 15 Surabaya

10. UKM Jehan Batik Jl. Banyu Urip Wetan Tengah Buntu 1/5 Surabaya

11. UKM Wilis \& Verda, JI. Banyu Urip Wetan 2/107 Surabaya

12. UKM Karya Ikat Jumput Mandiri JI. Pandegiling 1/44-1

13. KUB Batik WARNA AYU, JI Putat Jaya Punden I No.15

\section{References}

[1] Tjahjo, P. (1983. Dolly membedah Dunia Pelacuran Surabaya, kasus kompleks pelacuran Dolly. Jakarta: Grafiti Press.

[2] Jakob, S. (2000). Filsafat seni. Bandung: Penerbit ITB.

[3] Koentjaraningrat.. (1994). Kebudayaan Jawa. Jakarta: Balai Pustaka, p.25.

[4] Sunardi, S. (2004). Semiotika Negativa. Yogyakarta: Buku baik, pp.96-97.

[5] Sunardi, S. (2004). Semiotika Negativa. Yogyakarta: Buku baik, pp.103-105.

[6] Sunardi, S. (2004). Semiotika Negativa. Yogyakarta: Buku baik, pp.98.

[7] Hall, S. (2003). Representation: Cultural Representation and Signifying Practices. London: Sage Publication, p.17

[8] Bighell, J. (1997). Media Semiotics: An Introduction. New York: Manchester University Press, p.16

[9] Eriyanto. (2008). Analisis Wacana: Pengantar Analisis Teks Media. Yogyakarta: LKiS Yogyakarta, p. 7.

[10] Vera, N. (2014). Semiotika dalam Riset Komunikasi. Bogor: Ghalia, p.27.

[11] Sobur, A. (2013). Filasafat Komunikasi. Bandung: PT Remaja Rosdakarya, p. 262

[12] Budiono, H. (2008). Simbolisme Jawa. Yogyakarta: Penerbit Ombak.

[13] Suwardi, E. (2012). Falsafah Hidup Jawa. Yogyakarta: Penerbit Cakrawala.

[14] Sindung, H. (2013). Dunia Simbol Orang Jawa. Yogyakarta: Kepel Press.

[15] Edy, S. (2013). Candi Indonesia seri Jawa. Direktorat Pelestarian Cagar Budaya dan Permuseuman. 
[16] Sri Wintala, A. (2017). Asal Usul Sejarah Orang Jawa. Yogyakarta:

[17] Araska.

[18] Suwito. Sri, Yuwono. dkk. (2008). Buku Prajurit Kraton Yogyakarta, Filososfi dan Nilai Budaya yang Terkandung di dalamnya. Dinas Pariwisata dan Kebudayaan Yogyakarta 